\title{
Dust optical properties over North Africa and Arabian Peninsula derived from the AERONET dataset
}

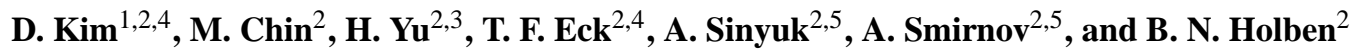 \\ ${ }^{1}$ Joint Center for Earth Systems Technology, University of Maryland Baltimore County, Baltimore, Maryland, USA \\ ${ }^{2}$ NASA Goddard Space Flight Center, Greenbelt, Maryland, USA \\ ${ }^{3}$ Earth System Science Interdisciplinary Center, University of Maryland, College Park, Maryland, USA \\ ${ }^{4}$ Universities Space Research Association, Columbia, Maryland, USA \\ ${ }^{5}$ Sigma Space Corporation, Lanham, Maryland, USA
}

Received: 3 June 2011 - Published in Atmos. Chem. Phys. Discuss.: 18 July 2011

Revised: 30 September 2011 - Accepted: 17 October 2011 - Published: 28 October 2011

\begin{abstract}
Dust optical properties over North Africa and the Arabian Peninsula are extracted from the quality assured multi-year datasets obtained at 14 sites of the Aerosol Robotic Network (AERONET). We select the data with (a) large aerosol optical depth (AOD $\geq 0.4$ at $440 \mathrm{~nm}$ ) and (b) small Ångström exponent $\left(\AA_{\text {ext }} \leq 0.2\right)$ for retaining high accuracy and reducing interference of non-dust aerosols. The result indicates that the major fraction of high aerosol optical depth days are dominated by dust over these sites even though it varies depending on location and time. We have found that the annual mean and standard deviation of single scattering albedo, asymmetry parameter, real refractive index, and imaginary refractive index for Saharan and Arabian desert dust is $0.944 \pm 0.005,0.752 \pm 0.014,1.498 \pm 0.032$, and $0.0024 \pm 0.0034$ at $550 \mathrm{~nm}$ wavelength, respectively. Dust aerosol selected by this method is less absorbing than the previously reported values over these sites. The weaker absorption of dust from this study is consistent with the studies using remote sensing techniques from satellite. These results can help to constrain uncertainties in estimating global dust shortwave radiative forcing.
\end{abstract}

\section{Introduction}

Dust is one of the major aerosol components in the global atmosphere that affects the Earth's climate through interacting with both solar and thermal infrared radiation. Dust also affects atmospheric dynamics, atmospheric chemistry, air quality, and ocean biogeochemistry over wide ranges of

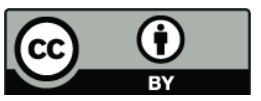

Correspondence to: D. Kim (dongchul.kim@nasa.gov) spatial and temporal scales (e.g., Husar et al., 2001; Haywood et al., 2005; Jickells et al., 2005). On a global average, dust contributes to about one quarter of aerosol optical depth (AOD) in the mid-visible wavelengths (Kinne et al., 2006). Dust is also light absorbing (Sokolik and Toon, 1999; Alfaro et al., 2004; Lafon et al., 2004 and 2006); it is estimated that more than half of aerosol absorption optical depth (AAOD) at $550 \mathrm{~nm}$ may come from dust (Chin et al., 2009). At shorter wavelengths the contribution of dust absorption is even larger, because dust is more absorbing in the UV range than in visible (Russell et al., 2010). Large uncertainties still remain in assessing the dust climate impacts. One of the major sources for the large uncertainties is associated with dust absorption properties of shortwave radiation is due to the complexity in dust size distribution, morphology, and mineral composition (Sokolik and Toon, 1999; Lafon et al., 2004, 2006).

The strength of dust absorption, or the imaginary part $(k)$ of complex refractive indices $(n+i k)$ is determined mainly by the iron oxide content in soil such as hematite and geothite (Patterson et al., 1977; Claquin et al., 1999; Sokolik and Toon, 1999; Alfaro et al., 2004; Lafon et al., 2004, 2006; Formenti et al., 2008; Derimian et al., 2008). Their absorption is highly variable due to the heterogeneous mineralogical content in soils. Early measurements show that dust is strongly absorbing with the imaginary refractive index of 0.0053 to 0.008 at $550 \mathrm{~nm}$ (Patterson et al., 1977; Shettle and Fenn, 1979). These data have been incorporated into the Optical Properties of Aerosols and Clouds (OPAC) dataset (Hess et al., 1998), which has been widely used to calculate dust absorption in models (Kinne et al., 2006; Forster et al., 2007). However more recent observations conducted in the Saharan desert region indicate that dust is much less absorbing with the imaginary refractive index of 0.0001 to 0.0046 at $550 \mathrm{~nm}$

Published by Copernicus Publications on behalf of the European Geosciences Union. 
(Kaufman et al., 2001; Colarco et al., 2002; Haywood et al., 2005, Petzold et al., 2009; McConnell et al., 2010). There is a pressing need to update dust absorption properties assumed in aerosol models with the most recent observations. One of such set of observations is the retrieval of aerosol absorption properties from the Aerosol Robotic Network (AERONET) (Dubovik and King, 2000; Dubovik et al., 2002). AERONET consists of more than 200 sites around the globe and has been providing uniformly calibrated, quality assured aerosol datasets for nearly two decades (Holben et al., 1998). Several studies have used the AERONET datasets to analyze aerosol absorption properties in dust dominated regions (Dubovik et al., 2000, 2002, and 2006; Smirnov et al., 2002a; Sinyuk et al., 2003; Eck et al., 2008, 2010). However, dust is often mixed with pollution and biomass burning smoke aerosols in the atmosphere, even in desert sites (Eck et al., 2010). To derive optical properties that can be representative of pure dust in models, it requires efforts to reduce the contributions by non-dust aerosols in the AERONET observations.

In this study, we extract the dust optical properties, including real and imaginary refractive index, and single scattering albedo, from multiyear AERONET measurements at 14 sites in and around the Saharan and Arabian Deserts. We use a threshold for the Ångström exponent of extinction to reduce contributions of non-dust aerosols, because dust generally has much larger size in source areas and hence smaller Ångström exponent than pollution and smoke aerosols. The rest of this paper is organized as follows. We briefly describe the AERONET inversion retrieval and optically based filter for minimizing non-dust aerosol contribution in Sect. 2. Results of dust optical properties are described in Sect. 3 on a monthly basis. Section 4 summarizes major conclusions from this analysis and discusses implications for assessing dust radiative forcing.

\section{AERONET data and analysis method}

AERONET provides sun photometer observations of AOD at up to 8 wavelength channels between 340 and $1640 \mathrm{~nm}$ at numerous sites around the globe (Holben et al., 1998, 2001) and angular distribution of sky radiance at four wavelengths $(440,675,870$, and $1020 \mathrm{~nm})$. In addition to the direct measurement of AOD, the inversion algorithm retrieves physical and optical properties of aerosols such as volume size distributions, the complex refractive index, single scattering albedo, and asymmetry parameter at 440, 675, 870, and $1020 \mathrm{~nm}$, under conditions of relatively high aerosol optical depth (AOD $\geq 0.4$ at $440 \mathrm{~nm}$ ) and large solar zenith angle $\left(>50^{\circ}\right)$ (Dubovik and King, 2000; Smirnov et al., 2000; Dubovik et al., 2002, 2006; Eck et al., 2008, 2010). Dust optical properties are retrieved with a model of shape mixtures of randomly oriented spheroids (Dubovik et al., 2006). Recent field measurements found that the measured optical

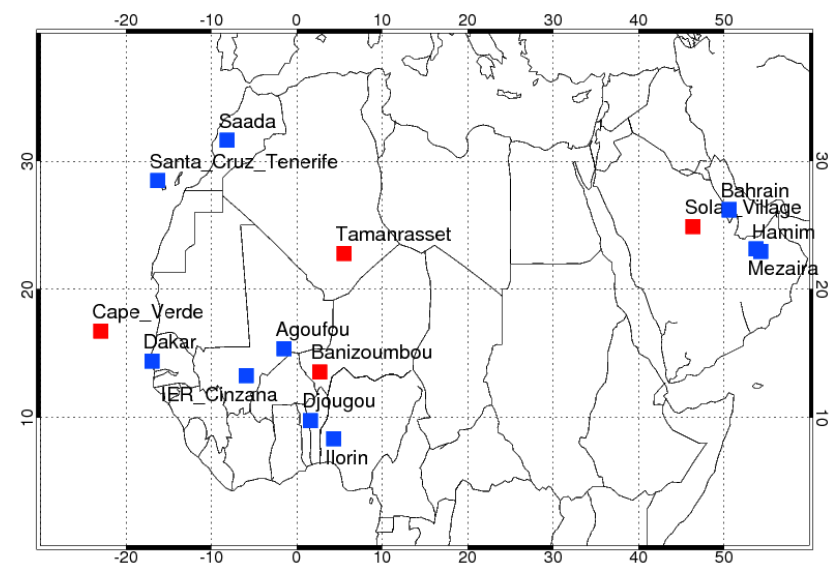

Fig. 1. The domain map and site location of the 14 AERONET sites selected for this study. Four sites marked with red squares are used for detailed analysis (see text).

properties are comparable to the AERONET retrievals (Petzold et al., 2009; McConnell et al., 2010).

In this study, we choose 14 AERONET sites in and around North Africa and the Arabia peninsula (Fig. 1) that are considered to be dust dominated sites. Multi-year aerosol data from these sites warrant a robust statistical analysis. While smoke and pollution are predominantly in the fine mode, dust aerosol is mainly in the coarse mode especially near the source regions. We therefore eliminate the data that are possibly influenced by smoke or pollution by selecting only coarse mode aerosol data (radii $\geq 1 \mu \mathrm{m}$ ) with Ångström exponent $\left(\AA_{\text {ext }}\right)$ smaller than a threshold. The Ångström exponent is a measure of the wavelength $(\lambda)$ dependence of aerosol optical depth $(\tau)$, and is inversely related to the particle size (i.e., a smaller $\AA_{\text {ext }}$ indicates larger particle size, and vice versa):

$\AA_{\text {ext }}=-\frac{\log \left(\tau_{\lambda_{1}} / \tau_{\lambda_{2}}\right)}{\log \left(\lambda_{1} / \lambda_{2}\right)}$

Measured AOD uncertainty is relatively small in the AERONET database, $\sim 0.01$ in the visible and near-infrared wavelengths (Eck et al., 1999), allowing for a very accurate calculation of $\AA_{\text {ext }}$ especially at the moderate to high AOD levels analyzed in this study. Previous studies showed that $\AA_{\text {ext }}$ is typically between 0.24 and 0.6 over the desert sites (e.g., Wang et al., 2004; Dubovik et al., 2002; Eck et al., 2008; Todd et al., 2007). Previous studies using AERONET data have found a strong relationship between $\AA_{\text {ext }}$ and aerosol absorption in both desert and non-desert sites (Eck et al., 2008, 2010). This indicates that the contribution of fine mode aerosols other than dust is not negligible even in dust regions. In this study we choose a $\AA_{\text {ext }}$ value of 0.2 or less, calculated with the Sunphotometer measured AOD at 440 and $870 \mathrm{~nm}$ wavelengths, as a criteria to extract dust (DU) from the complete AERONET data with $\tau \geq 0.4$ (ALL) over 14 selected dust sites. Such a criteria ensures 
Table 1. Annual mean and standard deviation of single scattering albedo, asymmetry parameter, complex refractive index of DU at $550 \mathrm{~nm}$ wavelength. Ångström exponent $\left(\AA_{\text {ext }}\right)$ is at $440-870 \mathrm{~nm}$. Sampling period is in the parenthesis of the first column and the number of DU and ALL days during the sampling period is in the last column. Maximum and minimum values are in parenthesis of the optical property related columns.

\begin{tabular}{|c|c|c|c|c|c|c|}
\hline & SSA & ASYM & REFR & $\begin{array}{l}\text { REFI } \\
\left(\times 10^{-3}\right)\end{array}$ & $\AA_{\text {ext }}$ & $\begin{array}{l}\text { DU (ALL) } \\
\text { Days }\end{array}$ \\
\hline $\begin{array}{l}\text { Cape Verde } \\
(1996-2009)\end{array}$ & $\begin{array}{l}0.949 \pm 0.006 \\
(0.866,0.989)\end{array}$ & $\begin{array}{l}0.767 \pm 0.006 \\
(0.707,0.792)\end{array}$ & $\begin{array}{l}1.458 \pm 0.007 \\
(1.387,1.600)\end{array}$ & $\begin{array}{l}2.389 \pm 0.323 \\
(0.5,8.5)\end{array}$ & $\begin{array}{l}0.130 \pm 0.014 \\
(-0.019,0.2)\end{array}$ & $\begin{array}{l}841 \\
(1264)\end{array}$ \\
\hline $\begin{array}{l}\text { Dakar } \\
(2001-2009)\end{array}$ & $\begin{array}{l}0.946 \pm 0.007 \\
(0.856,0.979)\end{array}$ & $\begin{array}{l}0.760 \pm 0.009 \\
(0.715,0.794)\end{array}$ & $\begin{array}{l}1.481 \pm 0.017 \\
(1.38,1.600)\end{array}$ & $\begin{array}{l}2.421 \pm 0.367 \\
(0.9,6.9)\end{array}$ & $\begin{array}{l}0.130 \pm 0.017 \\
(0.011,0.199)\end{array}$ & $\begin{array}{l}866 \\
(1793)\end{array}$ \\
\hline $\begin{array}{l}\text { Saada } \\
(2004-2009)\end{array}$ & $\begin{array}{l}0.936 \pm 0.009 \\
(0.891,0.967)\end{array}$ & $\begin{array}{l}0.750 \pm 0.008 \\
(0.716,0.772)\end{array}$ & $\begin{array}{l}1.486 \pm 0.018 \\
(1.436,1.600)\end{array}$ & $\begin{array}{l}3.135 \pm 0.565 \\
(1.5,6.4)\end{array}$ & $\begin{array}{l}0.156 \pm 0.026 \\
(0.031,0.198)\end{array}$ & $\begin{array}{l}149 \\
(754)\end{array}$ \\
\hline $\begin{array}{l}\text { Santa Cruz } \\
(2005-2009)\end{array}$ & $\begin{array}{l}0.939 \pm 0.008 \\
(0.923,0.960)\end{array}$ & $\begin{array}{l}0.756 \pm 0.013 \\
(0.738,0.786)\end{array}$ & $\begin{array}{l}1.467 \pm 0.023 \\
(1.429,1.501)\end{array}$ & $\begin{array}{l}2.894 \pm 0.326 \\
(1.6,3.8)\end{array}$ & $\begin{array}{l}0.149 \pm 0.012 \\
(0.111,0.188)\end{array}$ & $\begin{array}{l}49 \\
(119)\end{array}$ \\
\hline $\begin{array}{l}\text { Solar Village } \\
(1999-2008)\end{array}$ & $\begin{array}{l}0.941 \pm 0.009 \\
(0.892,0.974)\end{array}$ & $\begin{array}{l}0.742 \pm 0.004 \\
(0.717,0.794)\end{array}$ & $\begin{array}{l}1.531 \pm 0.028 \\
(1.417,1.600)\end{array}$ & $\begin{array}{l}2.312 \pm 0.322 \\
(1,5.2 .0)\end{array}$ & $\begin{array}{l}0.110 \pm 0.024 \\
(-0.082,0.199)\end{array}$ & $\begin{array}{l}1011 \\
(2393)\end{array}$ \\
\hline $\begin{array}{l}\text { Hamim } \\
(2004-2007)\end{array}$ & $\begin{array}{l}0.951 \pm 0.007 \\
(0.910,0.972)\end{array}$ & $\begin{array}{l}0.733 \pm 0.010 \\
(0.700,0.761)\end{array}$ & $\begin{array}{l}1.521 \pm 0.032 \\
2(1.449,1.600)\end{array}$ & $\begin{array}{l}2.029 \pm 0.443 \\
(1,4.5 .0)\end{array}$ & $\begin{array}{l}0.139 \pm 0.058 \\
(-0.028,0.199)\end{array}$ & $\begin{array}{l}157 \\
(1018)\end{array}$ \\
\hline $\begin{array}{l}\text { Bahrain } \\
(1998-2006)\end{array}$ & $\begin{array}{l}0.948 \pm 0.010 \\
(0.915,0.986)\end{array}$ & $\begin{array}{l}0.731 \pm 0.004 \\
(0.719,0.757)\end{array}$ & $\begin{array}{l}1.559 \pm 0.029 \\
(1.468,1.600)\end{array}$ & $\begin{array}{l}2.032 \pm 0.279 \\
(0.5,3.7)\end{array}$ & $\begin{array}{l}0.141 \pm 0.017 \\
(0.037,0.186)\end{array}$ & $\begin{array}{l}43 \\
(372)\end{array}$ \\
\hline $\begin{array}{l}\text { Mezaira } \\
(2004-2007)\end{array}$ & $\begin{array}{l}0.951 \pm 0.000 \\
(0.915,0.986)\end{array}$ & $\begin{array}{l}0.731 \pm 0.000 \\
(0.719,0.757)\end{array}$ & $\begin{array}{l}1.544 \pm 0.000 \\
(1.468,1.600)\end{array}$ & $\begin{array}{l}1.900 \pm 0.000 \\
(0.5,3.7)\end{array}$ & $\begin{array}{l}0.177 \pm 0.000 \\
(0.037,0.186)\end{array}$ & $\begin{array}{l}15 \\
(452)\end{array}$ \\
\hline $\begin{array}{l}\text { Banizoumbou } \\
(1995-2009)\end{array}$ & $\begin{array}{l}0.950 \pm 0.009 \\
(0.859,0.987)\end{array}$ & $\begin{array}{l}0.765 \pm 0.015 \\
(0.702,0.811)\end{array}$ & $\begin{array}{l}1.479 \pm 0.031 \\
(1.375,1.600)\end{array}$ & $\begin{array}{l}2.087 \pm 0.391 \\
(0.5,8.8)\end{array}$ & $\begin{array}{l}0.135 \pm 0.022 \\
(-0.026,0.200)\end{array}$ & $\begin{array}{l}1416 \\
(3006)\end{array}$ \\
\hline $\begin{array}{l}\text { Ilorin } \\
(1998-2009)\end{array}$ & $\begin{array}{l}0.940 \pm 0.009 \\
(0.786,0.973)\end{array}$ & $\begin{array}{l}0.753 \pm 0.011 \\
(0.714,0.788)\end{array}$ & $\begin{array}{l}1.514 \pm 0.023 \\
(1.433,1.600)\end{array}$ & $\begin{array}{l}2.565 \pm 0.563 \\
(0.9,14.0)\end{array}$ & $\begin{array}{l}0.157 \pm 0.012 \\
(0.052,0.199)\end{array}$ & $\begin{array}{l}82 \\
(1832)\end{array}$ \\
\hline $\begin{array}{l}\text { IER Cinzana } \\
(2004-2009)\end{array}$ & $\begin{array}{l}0.943 \pm 0.007 \\
(0.844,0.982)\end{array}$ & $\begin{array}{l}0.760 \pm 0.010 \\
(0.708,0.802)\end{array}$ & $\begin{array}{l}1.485 \pm 0.021 \\
(1.393,1.600)\end{array}$ & $\begin{array}{l}2.487 \pm 0.332 \\
(0.6,7.3)\end{array}$ & $\begin{array}{l}0.132 \pm 0.027 \\
(-0.015,0.200)\end{array}$ & $\begin{array}{l}828 \\
(1979)\end{array}$ \\
\hline $\begin{array}{l}\text { Agoufou } \\
(2003-2009)\end{array}$ & $\begin{array}{l}0.938 \pm 0.008 \\
(0.812,0.975)\end{array}$ & $\begin{array}{l}0.767 \pm 0.012 \\
(0.718,0.810)\end{array}$ & $\begin{array}{l}1.483 \pm 0.025 \\
(1.385,1.600)\end{array}$ & $\begin{array}{l}2.745 \pm 0.419 \\
(0.9,14.3)\end{array}$ & $\begin{array}{l}0.120 \pm 0.032 \\
(-0.048,0.200)\end{array}$ & $\begin{array}{l}1379 \\
(1993)\end{array}$ \\
\hline $\begin{array}{l}\text { Djougou } \\
(2004-2007)\end{array}$ & $\begin{array}{l}0.937 \pm 0.013 \\
(0.860,0.973)\end{array}$ & $\begin{array}{l}0.755 \pm 0.007 \\
(0.703,0.795)\end{array}$ & $\begin{array}{l}1.505 \pm 0.032 \\
(1.378,1.600)\end{array}$ & $\begin{array}{l}2.654 \pm 0.600 \\
(0.8,8.1)\end{array}$ & $\begin{array}{l}0.140 \pm 0.017 \\
(0.049,0.200)\end{array}$ & $\begin{array}{l}148 \\
(1526)\end{array}$ \\
\hline $\begin{array}{l}\text { Tamanrasset } \\
(2006-2009)\end{array}$ & $\begin{array}{l}0.947 \pm 0.006 \\
(0.909,0.965)\end{array}$ & $\begin{array}{l}0.766 \pm 0.004 \\
(0.751,0.780)\end{array}$ & $\begin{array}{l}1.456 \pm 0.014 \\
(1.387,1.506)\end{array}$ & $\begin{array}{l}2.371 \pm 0.256 \\
(1.5,4.5)\end{array}$ & $\begin{array}{l}0.114 \pm 0.042 \\
(0.012,0.195)\end{array}$ & $\begin{array}{l}150 \\
(190)\end{array}$ \\
\hline Overall & $0.944 \pm 0.005$ & $0.752 \pm 0.014$ & $1.498 \pm 0.032$ & $2.430 \pm 0.353$ & $0.138 \pm 0.018$ & \\
\hline
\end{tabular}

that the fine mode aerosols are mostly excluded from this analysis and the results are representative of nearly "pure" dust, even though the fine mode dust is also being excluded. Although sea salt aerosol is also mainly in the coarse mode and has small Ångström exponent ( $\sim 0.3-0.7$; Smirnov et al., $2002 b$ ), its contribution over these dust dominated sites is largely negligible.

Both ALL and DU data are first sampled from the AERONET Version 2 quality assured Level 2 inversion data taken at 15 min time intervals. We aggregated these instantaneous data to obtain daily means and then monthly means. We only consider monthly mean values when the number of sampling days is greater than three days in a particular month.

\section{Dust optical properties}

In this section, we first present detailed analysis at four representative sites, namely Tamanrasset in the center of Sahara desert, Cape Verde island near the west coast of North Africa, Banizoumbou in the Sahel region, and Solar Village in the Arabian Desert. These sites are marked as red squares in Fig. 1. We then summarize overall multi-year statistics of dust aerosol optical properties at all 14 sites. Dust optical properties analyzed here include single scattering albedo (SSA), asymmetry parameter (ASYM), and real and imaginary refractive index ( $n$ and $k$ ) at 440, 675, 870, and $1020 \mathrm{~nm}$. These are the key parameters for calculating dust radiative effects. The extracted dust optical properties are compared with those calculated from the complete AERONET data 
A. Cape Verde

B. Banizoumbou
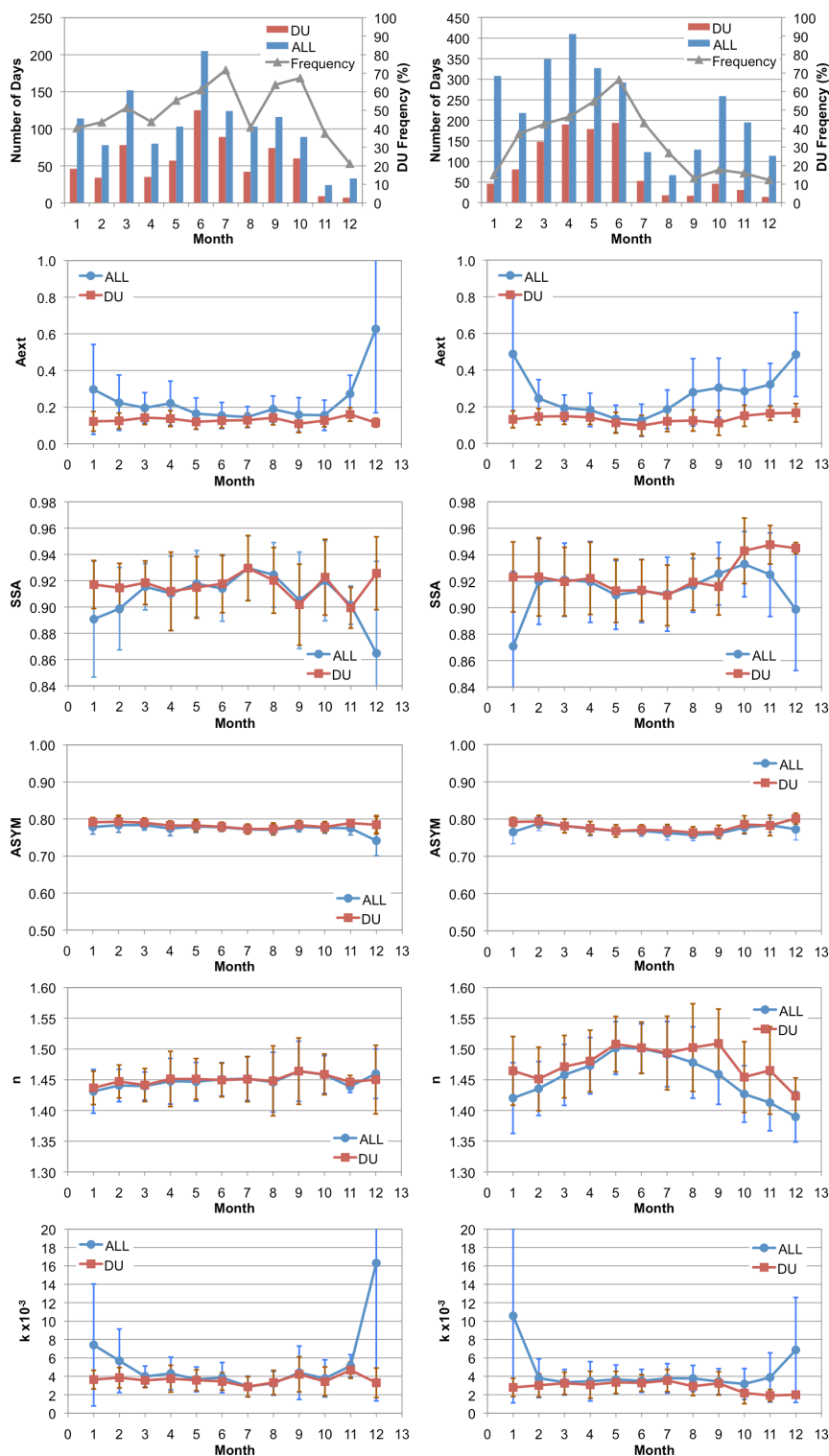
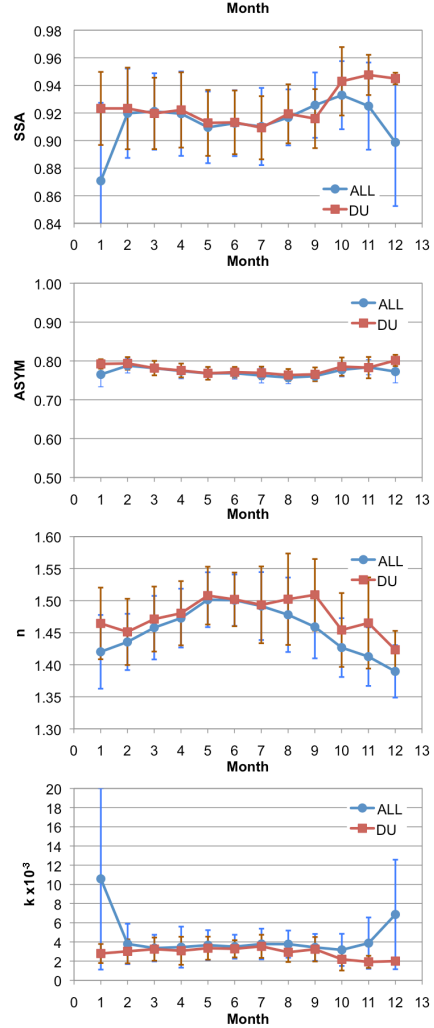

C. Tamanrasset
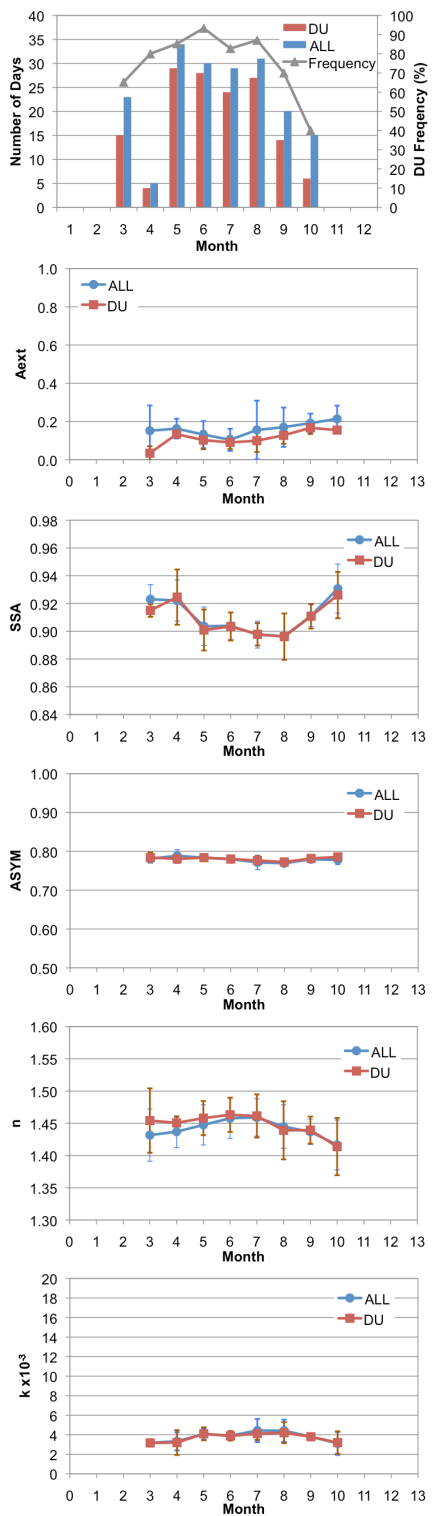

D. Solar Village
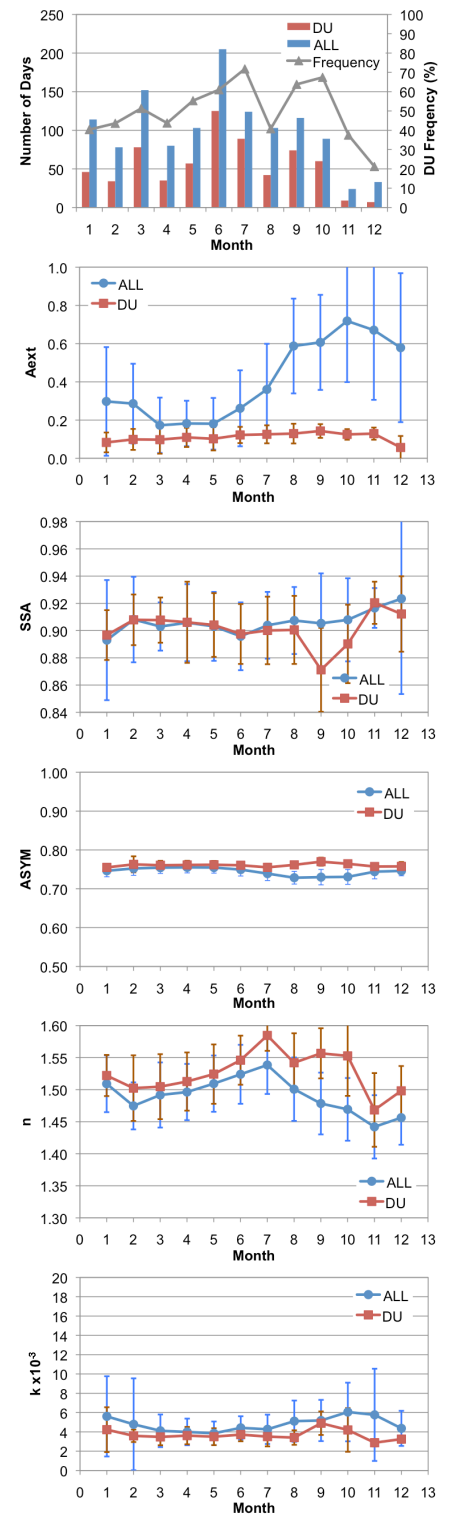

Fig. 2. Sampling frequency (first row) and DU optical properties of $\AA_{\text {ext }}(440-870 \mathrm{~nm}$ ) (second row), SSA (third row), ASYM (fourth row), and real and imaginary part of refractive indices (fifth and sixth row) at $440 \mathrm{~nm}$ at four selected sites (column 1-4).

set (ALL). Table 1 lists the site name, measurement period, average values of DU optical properties at a commonly used wavelength of $550 \mathrm{~nm}$ (using logarithmic interpolation between 440 and $670 \mathrm{~nm}), \AA_{\text {ext }}(440-870 \mathrm{~nm})$, and the DU and ALL days at the 14 sites.

Figure 2 shows the accumulated DU occurrence days of each month, occurrence frequency $\left(f_{\mathrm{DU}}\right.$, defined as the percentage of DU occurrence days in ALL days with $\tau \geq 0.4$ for both cases), and the extracted climatological monthly values of $\AA_{\text {ext }}$ and aerosol optical properties (at $440 \mathrm{~nm}$ ) at the four selected sites using all available measurements by the end of 2009. Over Cape Verde, the number of ALL days (blue bars) is generally between 70 and 200 days for all months except for November and December when data are rather sparse (below 30 days). The DU occurrence frequency $\left(f_{\mathrm{DU}}\right)$ is relatively low in the winter months $(\sim 20$ $50 \%)$, compared to the rest of the year $(\sim 50-90 \%)$. The lower $f_{\mathrm{DU}}$ in winter reflects the influence of biomass burning aerosol that are transported from the Sahel during the burning season (Tesche et al., 2009). As a result, there are significant differences between DU and ALL for $\AA_{\text {ext }}$, SSA, and the imaginary part of the refractive index $(k)$, especially in 

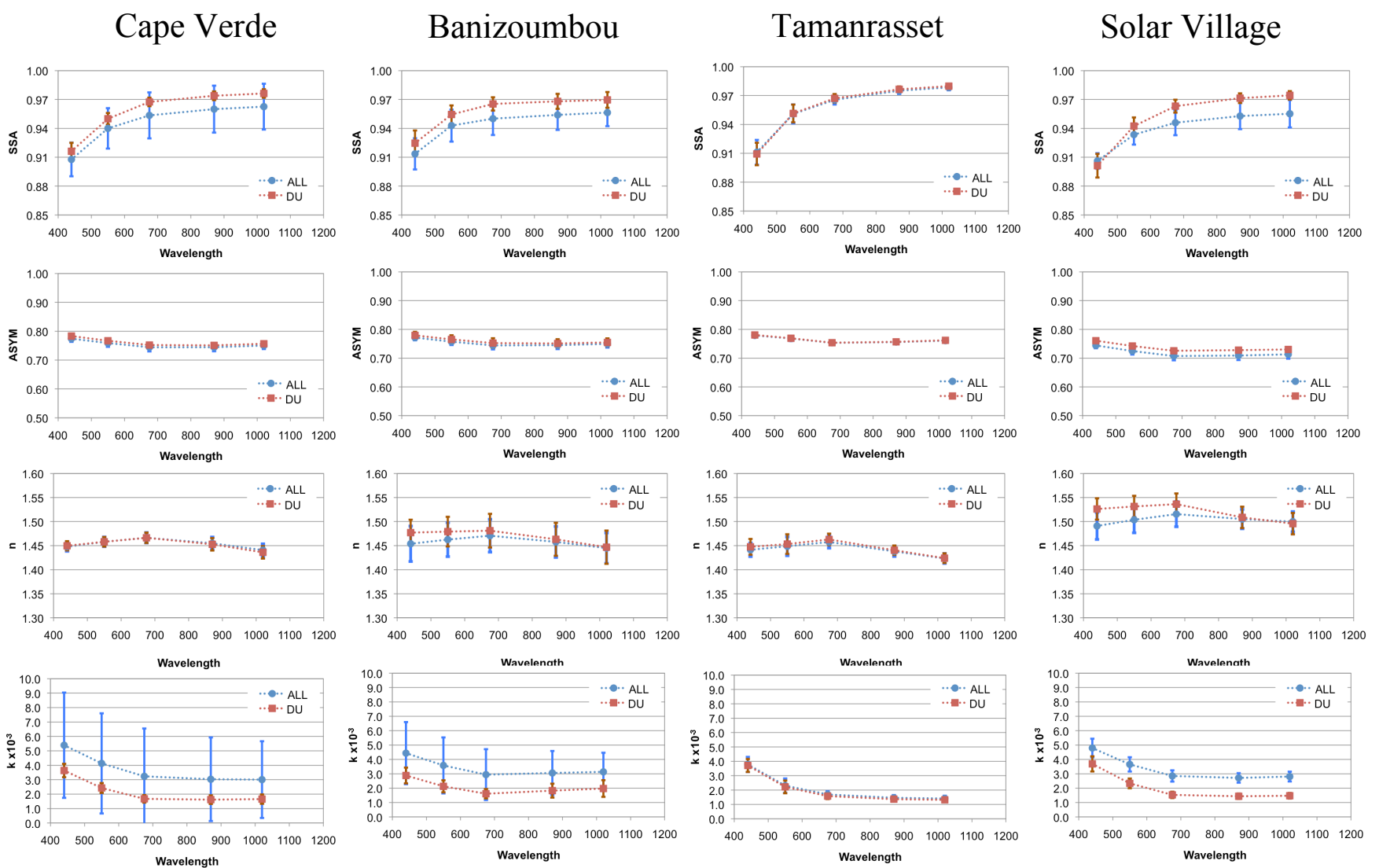

Fig. 3. Wavelength dependency of DU optical properties at four selected sites.

December and January. In these months DU data have much weaker absorption at $440 \mathrm{~nm}(\mathrm{SSA}=0.92-0.93)$ than ALL $($ SSA $=0.87-0.89)$. While the standard deviations of SSA and $k$ for DU have similar values for all months, those for ALL are much larger in winter than in other seasons, presumably reflecting a mixture of dust and biomass burning smoke in winter. There are no significant differences for asymmetry parameters (ASYM) and real part of the refractive index $(n)$ between DU and ALL, with ASYM of about 0.78 and $n$ of $1.42-1.46$ throughout the year.

Located in the middle of the Sahel, Banizoumbou (Fig. 2b) is heavily influenced by both dust and biomass burning. The $f_{\mathrm{DU}}$ value is generally $40-60 \%$ in spring and summer but drops significantly to below $20 \%$ in fall and winter, again suggesting the significant influence of biomass burning aerosols during the burning season. Similar to Cape Verde, $\AA_{\text {ext }}$ of DU is much lower than ALL during fall and winter but they are remarkably similar in spring and summer. DU absorption (SSA of $0.92-0.95$ at $440 \mathrm{~nm}$ ) is much weaker than ALL (SSA of 0.87-0.90) during winter, also similar to the results found at Ilorin, Nigeria by Eck et al. (2010). In other seasons, DU and ALL show comparable absorption with mean SSA of $0.91 \sim 0.95$ at $440 \mathrm{~nm}$. The imaginary part of refractive index for DU sampling is about
$3 \times 10^{-3}-4 \times 10^{-3}$, with a standard deviation that is a factor of 2-3 smaller than that from ALL. The real part of refractive index for DU is about 1.43-1.50, which is higher than ALL.

Tamanrasset (Fig. 2c) is in the center of the Saharan desert. The AERONET retrieval data frequency is quite low. The number of days for ALL is only about 20 to 30 days in each month during the measurement period (Table 1), and no data are available in winter. On the other hand, the $f_{\mathrm{DU}}$ is as high as $60-100 \%$ except in October (40\%), suggesting the dominance of DU in most months. As expected, there is no discernable difference in $\AA_{\text {ext }}$ and optical properties between ALL and DU. The mean SSA is $0.90-0.94$ at $440 \mathrm{~nm}$ and the imaginary part of refractive index is $2 \times 10^{-3}-4 \times 10^{-3}$. The strongest absorption occurs in May to August $(\mathrm{SSA}=0.90)$. Standard deviations of SSA and $k$ are relatively small at \pm 0.02 and \pm 0.0005 , respectively. The real part of refractive index for DU and ALL is about 1.42-1.46 except in January and February when there are low dust days. Back trajectory analysis showed that most of air mass is from East or NorthEast during the season. This shows that dust is the most dominant source of absorption and the variability of imaginary refractive index indicates different iron-oxide contents in each dust event. 

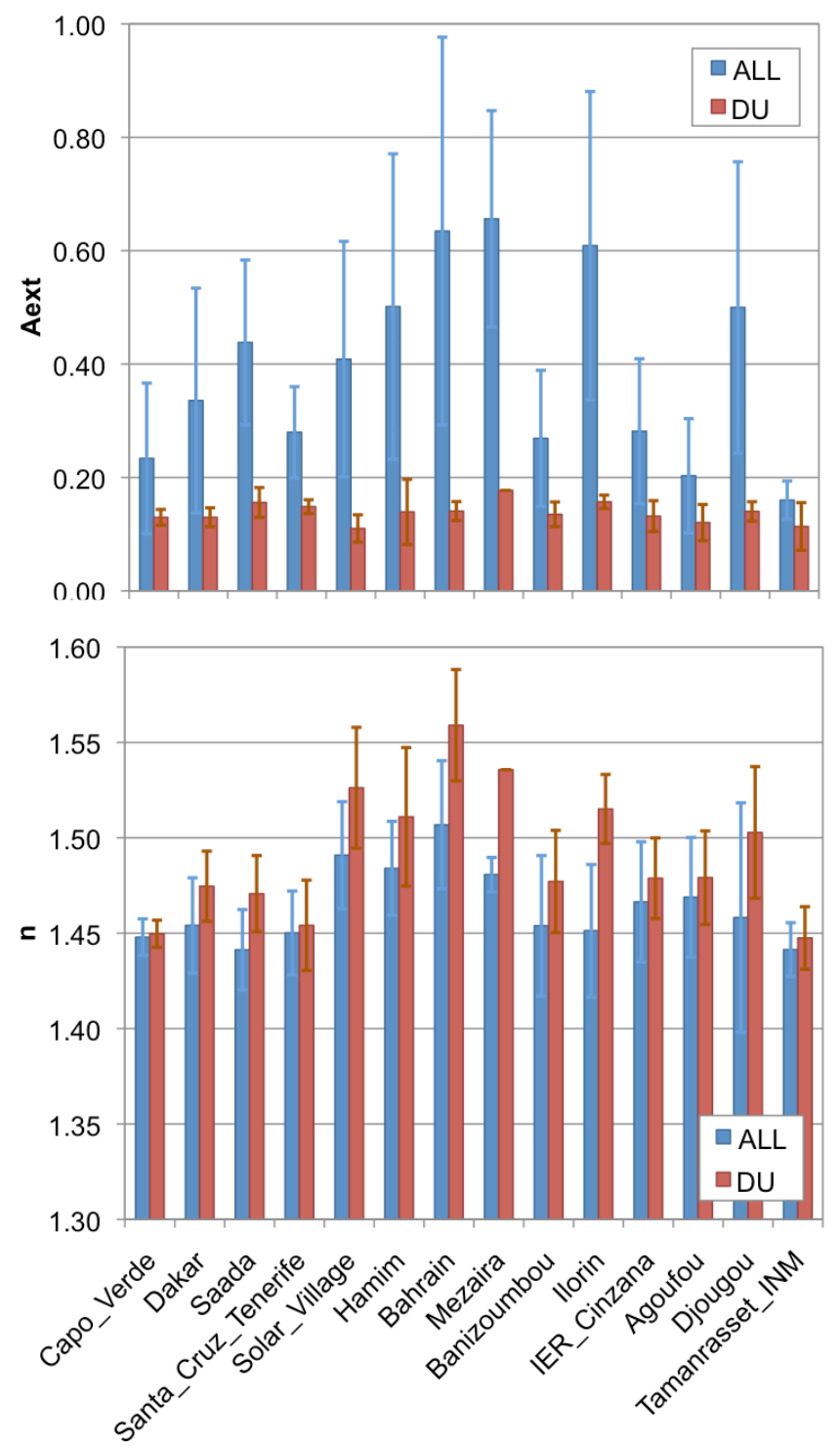
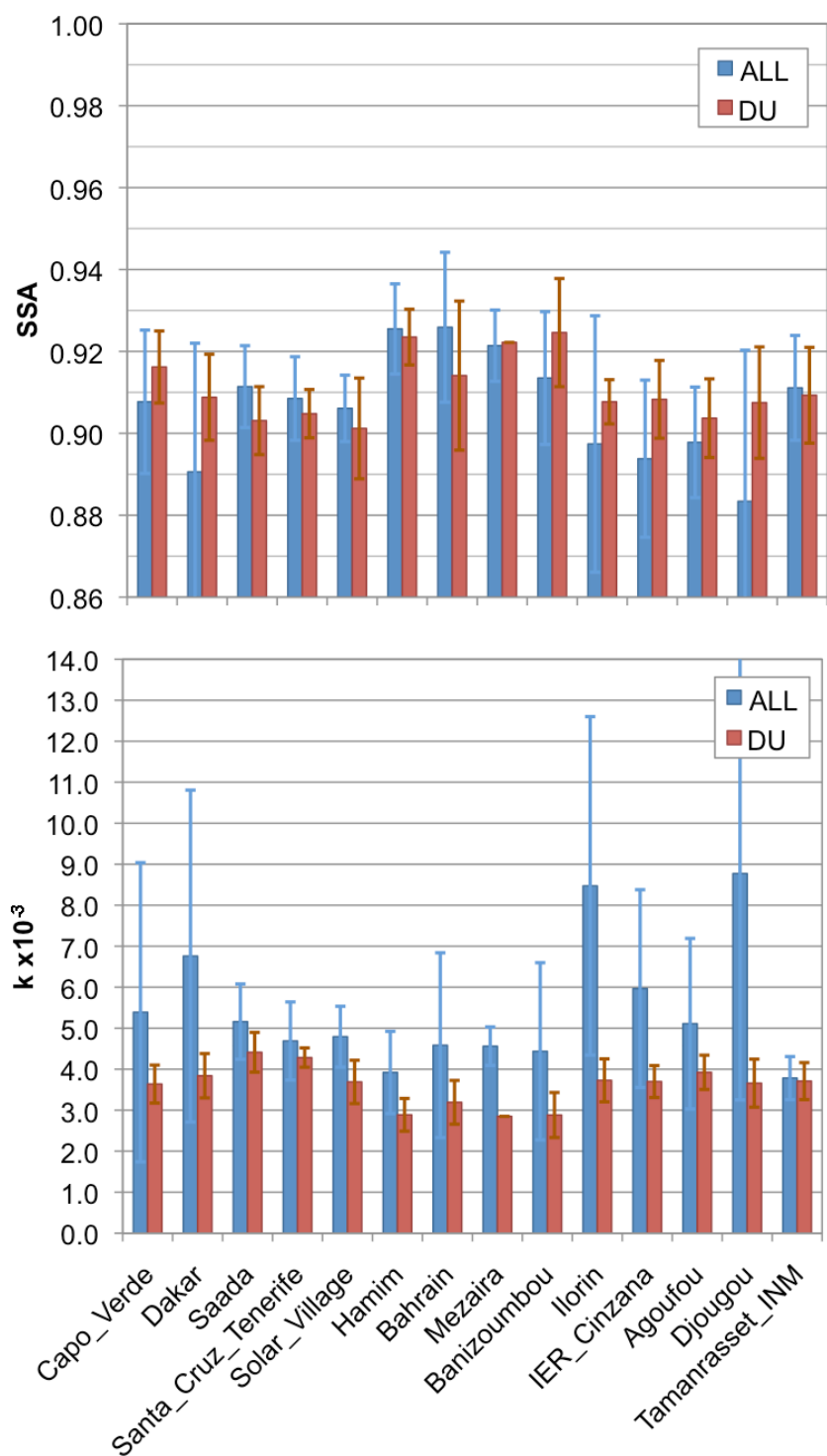

Fig. 4. Annual mean and standard deviation of $\AA_{\text {ext }}(440-870 \mathrm{~nm})$ and optical properties at $440 \mathrm{~nm}$ at all considered sites.

Solar Village (Fig. 2d) is relatively close to the industrialized Gulf region. The site has higher number of ALL days during spring and summer than other seasons with much higher $f_{\mathrm{DU}}$ in the first half of year $(\sim 60 \%)$ than the second half $(5-40 \%)$, suggesting the seasonal variation of aerosol mixtures. Accordingly, the $\AA_{\text {ext }}$ and optical properties (SSA, $k$ ) of DU and ALL are much closer to each other in the first half of the year than in the second half. The ASYM at Solar Village is about 0.77 for both DU and ALL, which is lower than $0.79-0.80$ in the other three sites.

Figure 3 shows the wavelength dependence of SSA, ASYM, $n$, and $k$ for DU and ALL in four selected sites. The increasing $\AA_{\text {ext }}$ patterns to wavelengths at three sites except for Solar Village are similar as in typical dust, however that of Solar Village is opposite. The increase of SSA with wavelength is a typical pattern for dust (Eck et al., 2008, 2010), due to the spectral absorption properties of iron oxides in dust (Sokolik and Toon, 1999). This is illustrated with the imaginary refractive index $(k)$, i.e., higher value at $440 \mathrm{~nm}$ than longer wavelengths. There is no clear wavelength dependence for real refractive index $(n)$ and ASYM. The standard deviation of DU is much smaller than that of ALL at all wavelengths, indicating the robustness of the DU sampling method.

Annual mean optical properties at $440 \mathrm{~nm}$ from all 14 sites (in Fig. 1) are summarized in Fig. 4. The first noticeable result is the largely redueced $\AA_{\text {ext }}$ and its variability in DU from ALL. The extracted resulting $\AA_{\text {ext }}$ of DU is very similar across the 14 sites. Another noticeable difference between DU and ALL is that the standard deviation of SSA and $k$ from DU is a factor of two to three lower than those from ALL. At the commonly referenced wavelength $550 \mathrm{~nm}$, 

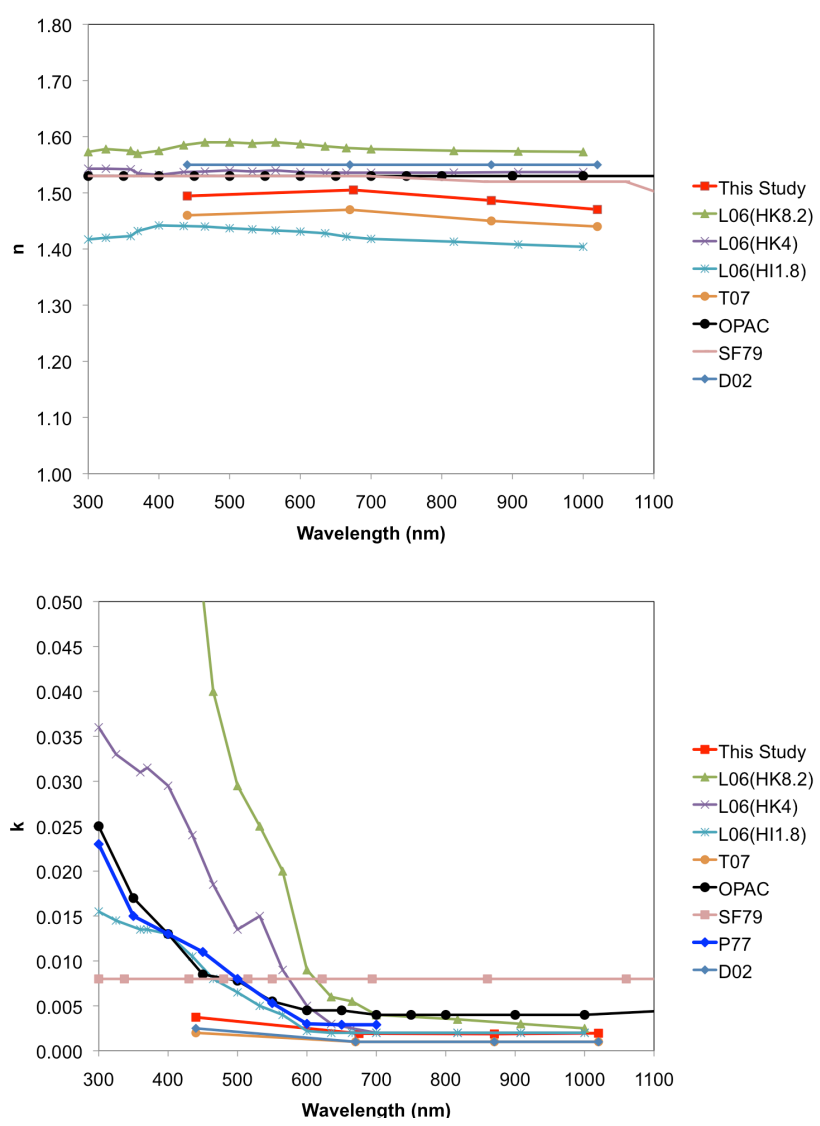

Fig. 5. Real and imaginary refractive index of the dust determined from AERONET (DU) from the current study. T07 is from Todd et al. (2007), OPAC is from Hess et al. (1998), SF79 is from Shettle and Fenn (1979), L06 is from Lafon et al. (2006), and D02 is the Bahrain site (most abosrobing site) in Dubovik et al. (2002). Different volume fractions (\%) of iron oxide in the hematite-kaolinite (HK) and hematite-illite (HI) aggregates are shown in the parenthesis of L06.

the annual mean and standard deviation of SSA, ASYM, $n$, and $k$ of DU at the 14 sites are $0.944 \pm 0.005,0.752 \pm 0.014$, $1.498 \pm 0.032$, and $0.0024 \pm 0.0035$, respectively.

\section{Discussion}

It is worth noting that in general DU is less absorbing than ALL over the North African sites but more absorbing at the Arabian sites (Fig. 4). A possible explanation is that the DU filter has effectively removed the fine mode aerosols, which is mostly the more absorbing biomass burning aerosol over North Africa but less absorbing pollution aerosols (such as sulfate) over Arabian Desert and two sites near Mediterranean of Saada and Santa Cruz Tenerife. Background aerosols may also affect the results. Figure 5 shows the comparisons of dust refractive indices from this study with various previous studies (Patterson et al., 1977 or P77; Shettle and Fenn,1979 or SF79; Hess et al., 1998 or OPAC; Lafon et al., 2006 or L06; Todd et al., 2007 or T07). For L06, multiple lines represent different iron oxides fractions in the soil samples. As noted in Sect. 1, many models currently use the OPAC database (Hess et al., 1998). The real part of refractive index has little wavelength dependence with values in the range of 1.40-1.60. However, different studies show very large differences in the imaginary part of refractive index, particularly in the UV and mid-visible range. In near infrared, our results agree with L06 and L06-HK4 very well, which is about a factor of 2 higher than T07 but in general more than a factor of 2 lower than OPAC and L06-HK8.2. In shorter wavelengths, our results are about a factor of 2 higher than T07 but substantially lower than other studies. The discrepancy increases sharply with decreasing wavelength. The iron oxide fraction of the sampled dust in the range of 1.8$8.2 \%$ is a major reason for the large range of the imaginary refractive index as shown by Lafon et al. (2006). It is worthy to note that the diatom aerosol (from fossilized plankton) is a major dust compound in lakebeds such as the Bodélé (Todd et al., 2007), which is not represented in the dust samples in Lafon et al. (2006). Our results suggest that atmospheric absorption and heating by dust might be lower than those calculated using OPAC dust absorption properties.

We have used a critical $\AA_{\text {ext,crit }}$ of 0.2 in this study to select nearly "pure" dust in source regions. This selection would also exclude fine mode dust particles. However, the similar values of $\AA_{\text {ext }}$ between ALL and DU during dust dominant season (Fig. 2) imply that most dust aerosols are in the coarse mode. We further examine if the derived dust optical properties are sensitive to the chosen threshold value of $\AA_{\text {ext,crit }}$; our sensitivity test shows that SSA gradually decreases with increasing $\AA_{\text {ext,crit }}$ for all Saharan sites, although individual sites may exhibit the opposite trend. Our method of removing non-dust aerosols from the AERONET product does not always work well. For example, the derived SSA in Blida is opposite to the change in imaginary part of refractive index (k) probably due to the influence by background aerosols. Also we could not find meaningful results over China because of the constant presence of other type of aerosols, such as fine mode pollution aerosols, which makes the selection of "pure" dust difficult. Also note that we did not consider the effect of internally mixed dust and other aerosols.

\section{Conclusions}

Given that dust aerosol is dominated by larger particles especially over the source region and Ångström exponent $\left(\AA_{\text {ext }}\right)$ is inversely related to the particle size, we have used the $\AA_{\text {ext }}<0.2$ as a threshold to extract dust (DU) from the AERONET dataset. We have applied this sampling method to the multi-year AERONET datasets at 14 sites in and around the Saharan and Arabian Deserts. Our analysis showed that the method works generally well in minimizing 
the influences of non-dust aerosols. The DU sampling constitutes $40-80 \%$ of ALL datasets, depending on sampling sites. The largest differences of optical properties between DU and ALL appear in the biomass burning season in northern Africa. In general, DU is less absorbing than ALL in the Saharan and Sahelian regions while DU is more absorbing than ALL in the Arabian Desert. A possible explanation is the contribution by other aerosols, such as non-absorbing sulfate versus more absorbing biomass burning aerosols, in the ALL. The variability of aerosol optical properties for DU is much smaller than that for ALL. The absorption variability in DU may be attributed to the variability of iron-oxides contents in different dust areas. Interpolating the multi-spectral optical properties to a commonly used wavelength of $550 \mathrm{~nm}$, we find that the mean and standard deviation of single scattering albedo, asymmetry parameter, real refractive index, and imaginary refractive index of DU in Saharan and Arabian dust are $0.946 \pm 0.005,0.752 \pm 0.014,1.498 \pm 0.032$, and $0.0025 \pm 0.0036$, respectively. In comparison, those of ALL are $0.932 \pm 0.011,0.738 \pm 0.004,1.475 \pm 0.011$, and $0.0045 \pm 0.0014$, respectively, at $550 \mathrm{~nm}$.

There exist uncertainties and limitations in the method used here when non-dust aerosol is significantly high (e.g., Blida and China) or the number of sampling days are not large enough (e.g., China). To obtain the dust optical properties over those area may have to rely on event-based or in-situ measurements.

Acknowledgements. This work is supported by NASA Modeling, Analysis and Prediction (MAP) and EOS Programs. We would like to thank the principal investigators (D. Tanré, B. Mougenot, B. Duchemin, E. Cuevas-Agullo, N. Al-Abbadi, R. T. Pinker, B. Chatenet, P. Goloub, and E. Cuevas-Agullo) and technicians of AERONET sites used in this study.

Edited by: B. N. Duncan

\section{References}

Alfaro, S. C., Lafon, S., Rajot, J. L., Formenti, P., Gaudichet, A., and Maillé, M.: Iron oxides and light absorption by pure desert dust: An experimental study, J. Geophys. Res., 109, D08208, doi:10.1029/2003JD004374, 2004.

Mian Chin, Diehl, T., Dubovik, O., Eck, T. F., Holben, B. N., Sinyuk, A., and Streets, D. G.: Light absorption by pollution, dust, and biomass burning aerosols: a global model study and evaluation with AERONET measurements, Ann. Geophys., 27, 3439-3464, doi:10.5194/angeo-27-3439-2009, 2009.

Claquin, T., Schulz, M., and Balkanski, Y. J.: Modeling the mineralogy of atmospheric dust sources, J. Geophys. Res., 104, 2224322256, 1999.

Colarco, P. R., Toon, O. B., Torres, O., and Rasch, P. J.: Determining the UV imaginary part of refractive index of Saharan dust particles from TOMS data and a three dimensional model of dust transport, J. Geophys. Res., 107, 4289, doi:10.1029/2001JD000903, 2002.
Derimian, Y., Karnieli, A., Kaufman, Y. J., Andreae, M. O., Andreae, T. W., Dubovik, O., Maenhaut, W., and Koren, I.: The role of iron and black carbon in aerosol light absorption, Atmos. Chem. Phys., 8, 3623-3637, doi:10.5194/acp-8-3623-2008, 2008.

Dubovik, O. and King, M. D.: A flexible inversion algorithm for retrieval of aerosol optical properties from Sun and sky radiance measurements, J. Geophys. Res., 105, 20673-20696, 2000.

Dubovik, O., Smirnov, A., Holben, B. N., King, M. D., Kaufman, Y. J., Eck, T. F., and Slutsker, I.: Accuracy assessments of aerosol optical properties retrieved from Aerosol Robotic Network (AERONET) Sun and sky radiance measurements, J. Geophys. Res., 105, 9791-9806, 2000.

Dubovik, O., Holben, B. N., Eck, T. F., Smirnov, A., Kaufman, Y. J., King, M. D., Tanré, D., and Slutsker, I.: Variability of absorption and optical properties of key aerosol types observed in worldwide locations, J. Atmos. Sci., 59, 590-608, 2002.

Dubovik, O., Sinyuk, A., Lapyonok, T., Holben, B. N., Mishchenko, M., Yang, P., Eck, T. F., Volten, H., Muñoz, O., Veihelmann, B., van der Zande, W. J., Leon, J.-F., Sorokin, M., and Slutsker, I. The application of spheroid models to account for aerosol particle nonsphericity in remote sensing of desert dust, J. Geophys. Res., 111, D11208, doi:10.1029/2005JD006619, 2006.

Eck, T. F., Holben, B. N., Reid, J. S., Dubovik, O., Smirnov, A., O'Neill, N. T., Slutsker, I., and Kinne, S.: Wavelength dependence of the optical depth of biomass burning, urban, and desert dust aerosol, J. Geophys. Res., 104, 31333-31349, 1999.

Eck, T. F., Holben, B. N., Reid, J. S., Sinyuk, A., Dubovik, O., Smirnov, A., Giles, D., O’Neill, N. T., Tsay, S.-C., Ji, Q., Mandoos, A. A., Khan, M. R., Reid, E. A., Schafer, J. S., Sorokine, M., Newcomb, W., and Slutsker, I.: Spatial and temporal variability of column-integrated aerosol optical properties in the southern Arabian Gulf and United Arab Emirates in summer, J. Geophys. Res., 113, D01204, doi:10.1029/2007JD008944, 2008.

Eck, T. F., Holben, B. N., Sinyuk, A., Pinker, R. T., Goloub, P., Chen, H., Chatenet, B., Li, Z., Singh, R. P., Tripathi, S. N., Reid, J. S., Giles, D. M., Dubovik, O., O’Neill, N. T., Smirnov, A., Wang, P., and Xia, X.: Climatological aspects of the optical properties of fine/coarse mode aerosol mixtures, J. Geophys. Res., 115, D19205, doi:10.1029/2010JD014002, 2010.

Formenti, P., Rajot, J. L., Desboeufs, K., Caquineau, S., Chevaillier, S., Nava, S., Gaudichet, A., Journet, E., Triquet, S., Alfaro, S., Chiari, M., Haywood, J., Coe, H., and Highwood, E.: Regional variability of the composition of mineral dust from western Africa: Results from the AMMA SOP0/DABEX and DODO field campaigns, J. Geophys. Res., 113, D00C13, doi:10.1029/2008JD009903, 2008.

Forster, P., Ramaswamy, V., Artaxo, P., Berntsen, T., Betts, R., Fahey, D., Haywood, J., Lean, J., Lowe, D., Myhre, G., Nganga, J., Prinn, R., Raga, G., Schulz, M., and Dorland, R. V.: Changes in Atmospheric Constituents and in Radiative Forcing, in: Climate Change 2007: The Physical Science Basis, Contribution of Working Group I to the Fourth Assessment Report of the Intergovernmental Panel on Climate Change, edited by: Solomon, S., Qin, D., Manning, M., Chen, Z., Marquis, M., Averyt, K. B., Tignor, M., and Miller, H. L., Cambridge University Press, Cambridge, UK and New York, NY, USA, 2007.

Haywood, J. M., Allan, R. P., Culverwell, I., Slingo, A., Milton, S., Edwards, J., and Clerbaux, N.: Can desert dust ex- 
plain the outgoing longwave radiation anomaly over the Sahara during July 2003?, J. Geophys. Res., 110, D05105, doi:10.1029/2004JD005232, 2005.

Hess, M., Köpke, P., and Schult, I.: Optical properties of aerosols and clouds: The software package OPAC, B. Am. Meteorol. Assoc., 79, 831-844, 1998.

Holben, B. N., Eck, T. F., Slutsker, I., Tanre, D., Buis, J. P., Setzer, A., Vermote, E., Reagan, J. A., Kaufman, Y. J., Nakajima, T., Lavenu, F., Jankowiak, F., and Smirnov, A.: AERONET - A federated instrument network and data archive for aerosol characterization, Remote Sens. Environ., 66, 1-16, 1998.

Husar, R. B., Tratt, D. M., Schichtel, B. A., Falke, S. R., Li, F., Jaffe, D., Gasso, S., Gill, T., Laulainen, N. S., Lu, F., Reheis, M. C., Chun, Y., Westphal, D., Holben, B. N., Gueymard, C., McKendry, I., Kuring, N., Feldman, G. C., McClain, C., Frouin, R. J., Merrill, J., DuBois, D., Vignola, F., Murayama, T., Nickovic, S., Wilson, W. E., Sassen, K., Sugimoto, N., and Malm, W. C.: Asian dust events of April 1998, J. Geophys. Res., 106, 18317-18330, 2001.

Jickells, T. D., An, Z. S., Andersen, K. K., Baker, A. R., Bergametti, G., Brooks, N., Cao, J. J., Boyd, P. W., Duce, R. A., Hunter, K. A., Kawahata, H., Kubilay, N., LaRoche, J., Liss, P. S., Mahowald, N., Prospero, J. M., Ridgwell, A. J., Tegen, I., and Torres, R.: Global iron connections between desert dust, ocean biogeochemistry, and climate, Science, 308, 67-71, 2005.

Kaufman, Y. J., Tanre, D., Dubovik, O., Karnieli, A., and Remer, L. A.: Absorption of sunlight by dust as inferred from satellite and ground-based remote sensing, Geophys. Res. Lett., 28, 14791482, 2001.

Kinne, S., Schulz, M., Textor, C., Guibert, S., Balkanski, Y., Bauer, S. E., Berntsen, T., Berglen, T. F., Boucher, O., Chin, M., Collins, W., Dentener, F., Diehl, T., Easter, R., Feichter, J., Fillmore, D., Ghan, S., Ginoux, P., Gong, S., Grini, A., Hendricks, J., Herzog, M., Horowitz, L., Isaksen, I., Iversen, T., Kirkevåg, A., Kloster, S., Koch, D., Kristjansson, J. E., Krol, M., Lauer, A., Lamarque, J. F., Lesins, G., Liu, X., Lohmann, U., Montanaro, V., Myhre, G., Penner, J., Pitari, G., Reddy, S., Seland, O., Stier, P., Takemura, T., and Tie, X.: An AeroCom initial assessment - optical properties in aerosol component modules of global models, Atmos. Chem. Phys., 6, 1815-1834, doi:10.5194/acp-6-1815-2006, 2006.

Lafon, S., Rajot, J.-L., Alfaro, S. C., and Gaudichet, A.: Quantification of iron oxides in desert aerosol, Atmos. Environ., 38, 1211-1218, 2004.

Lafon, S., Sokolik, I. N., Rajot, J. L., Caquineau, S., and Gaudichet, A.: Characterization of iron oxides in mineral dust aerosols: implications for light absorption, J. Geophys. Res., 111, D21207, doi:10.1029/2005JD007016, 2006.

McConnell, C. L., Formenti, P., Highwood, E. J., and Harrison, M. A. J.: Using aircraft measurements to determine the refractive index of Saharan dust during the DODO Experiments, Atmos. Chem. Phys., 10, 3081-3098, doi:10.5194/acp-10-3081-2010, 2010.
Patterson, E. M., Gillette, D. A., and Stockton, B. H.: Complex index of refraction between 300 and $700 \mathrm{~nm}$ for Saharan aerosols, J. Geophys. Res., 82, 3153-3160, 1977.

Petzold, A., Rasp, K., Weinzierl, B., Esselborn, M., Hamburger, T., Dörnbrack, A., Kandler, K., Schütz, L., and Knippertz, P., Fiebig, M., and Virkkula, A.: Saharan dust refractive index and optical properties from aircraft-based observations during SAMUM 2006, Tellus Ser. B, 61, 118-130, 2009.

Russell, P. B., Bergstrom, R. W., Shinozuka, Y., Clarke, A. D., DeCarlo, P. F., Jimenez, J. L., Livingston, J. M., Redemann, J., Dubovik, O., and Strawa, A.: Absorption Angstrom Exponent in AERONET and related data as an indicator of aerosol composition, Atmos. Chem. Phys., 10, 1155-1169, doi:10.5194/acp10-1155-2010, 2010.

Shettle, E. P. and Fenn, R. W.: Models for the Aerosols for the Lower Atmosphere and the Effects of Humidity Variations on Their Optical Properties, AFGL-TR-79-0214 Environmental Research Papers No. 676, 1979.

Sinyuk, A., Torres, O., and Dubovik, O.: Combined use of satellite and surface observations to infer the imaginary part of refractive index of Saharan dust, Geophys. Res. Lett., 30, 1081, doi:10.1029/2002GL016189, 2003.

Smirnov, A., Holben, B. N., Eck, T. F., Dubovik, O., and Slutsker, I.: Cloud screening and quality control algorithms for the AERONET data base, Remote Sens. Environ., 73, 337-349, 2000.

Smirnov, A., Holben, B. N., Dubovik, O., O’Neill, N. T., Eck, T. F., Westphal, D. L., Goroch, A. K., Pietras, C., and Slutsker, I.: Atmospheric Aerosol Optical Properties in the Persian Gulf, J. Atm. Sci., 59, 620-634, 2002a.

Smirnov, A., Holben, B. N., Kaufman, Y. J., Dubovik, O., Eck, T. F., Slutsker, I., Pietras, C., and Halthore, R.: Optical properties of atmospheric aerosol in maritime environments, J. Atmos. Sci., 59, 501-523, 2002b.

Sokolik, I. N. and Toon, O. B.: Incorporation of mineralogical composition into models of the radiative properties of mineral aerosol from UV to IR wavelengths, J. Geophys. Res, 104, 9423-9444, 1999.

Tesche, M., Ansmann, A., Müller, D., Althausen, D., Engelmann, R., Freudenthaler, V., and Groß, S.: Vertically resolved separation of dust and smoke over Cape Verde using multiwavelength Raman and polarization lidars during Saharan Mineral Dust Experiment 2008, J. Geophys. Res., 114, D13202, doi:10.1029/2009JD011862, 2009.

Todd, M. C., Washington, R., Martins, J. V., Dubovik, O., Lizcano, G., M'Bainayel, S., and Engelstaedter, S.: Mineral dust emission from the Bodélé Depression, northern Chad, during BoDEx 2005, J. Geophys. Res., 112, D06207, doi:10.1029/2006JD007170, 2007.

Wang, J., Xia, X., Wang, P., and Christopher, S. A.: Diurnal variability of dust aerosol optical thickness and Angström exponent over dust source regions in China, Geophys. Res. Lett., 31, L08107, doi:10.1029/2004GL019580, 2004. 